[Version for internal use only. Please refer to the published version only: https://www.rem.routledge.com/articles/dannunzio-gabriele-1863-1938]

Gabriele d'Annunzio, Italian poet, novelist, short story writer, dramatist, journalist, essayist and scriptwriter, was a leading Italian author in the late 19th and early 20th centuries. Since 1914, he also played an active role in Italian politics and became a national war hero and ideologist of the nationalists. His nonconformist model of aesthetic life (life as a work of art), his successful literary career, his political engagement in the Great War, and even his scandalous affairs surrounded his life with a legendary aura and made him one of the most striking personalities of the period in Italy, where he was and still is called, by antonomasia, the "Vate" (the Bard). Affirming literature's capability of influencing life style, he conditioned Italian language, fashion and everyday life, throughout a rhetorical-ideological model, of which he himself was the living embodiment, the so called Dannunzianism. He was a writer of international acclaim and it has often been argued that he lead Italian culture out of its provincialism by merging international cultural tendencies, such as aestheticism and symbolism, with Italy's national literary tradition and its Christian, Latin and ancient Greek roots.

The prominence of his legacy, innovative yet embedded in national tradition, is not only attested by a rich and controversial critical debate but even by the tribute paid to him by next generations of poets who felt compelled to face his literary model before finding a voice of their own, as Eugenio Montale said, Italian (antidannunzianist) poet and Nobel Prize in Literature in 1975.

Near the end of his life d'Annunzio supervised the publication of his works (Tutte le opere di Gabriele d'Annunzio, 1927-1936), undertaken by the Government and published in 49 volumes divided into four sections: poetry (Versi d'amore e di gloria), dramas (Tragedie, sogni, misteri), novels and short stories (Prose di romanzi) and other texts (Prose di ricerca, di lotta, di comando, di conquista, di tormento, d'indovinamento, di rinnovamento, di celebrazione, di rivendicazione, di liberazione, di favole, di giochi, di baleni). He presented this ultimate collection as his literary legacy to the nation, which also received the Vittoriale degli Italiani, d'Annunzio's monumental auto-celebrative private house. Incredibly gifted, especially as a poet, he wrote absolute masterpieces such as II piacere (The Pleasure 1898) where he introduces the leitmotiv of the superiority of the artist; Alcyone (Halcyon 1904), third book of the Laudi del cielo del mare della terra e degli eroi (In Praise of Sky, Sea, Earth, and Heroes), which represents his sensual perception of the world and the artist's attempt to communicate with the divine essence of nature; Notturno (1921) the anti-novel of d'Annunzio's war (from its beginning to Fiume). D'Annunzio believed that literature was the verbalization of the divine heart of nature and saw the artist as the living expression of this nature. D'Annunzio anticipated Italian modernism, yet unlike many modernist writers in Italy he still conceived art as a closed epistemological system and postulates an active role of the artist who rules and explains the world. 


\section{List of works:}

Complete works:

Prose di Romanzi, Versi d'amore e di gloria, Tutte le novelle, Scritti giornalistici, Prose di ricerca, Tragedie, sogni e misteri, Milano: Mondadori, 1984-2013.

Major works in translation:

The child of pleasure and also The pleasure and Pleasure (1889)

The intruder and also The victim (1892)

The flame of life and also The flame (1900)

Tales of my native town (1902)

Halcyon (1903)

The daughter of Jorio (1903)

Nocturne and also Notturno (1921)

\section{References and further readings:}

Hughes-Hallett, L. (2013), The Pike. Gabriele d'Annunzio. Poet, seducer and preacher of war, London: Fourth Estate; with the title Gabriele d'Annunzio. Poet, seducer and preacher of war, New York: Alfred A. Knopf

Costa, S. (2012) D’Annunzio, Roma: Salerno

Andreoli, A. (2004) D’Annunzio, Bologna: II Mulino

Ledeen, M. A. (2002), D'Annunzio. The first duce, New Brunswick: Transaction Publishers

Lewis, P. (2000), Modernism, nationalism, and the novel, Cambridge, Cambridge University Press

Woodhouse, J. R. (1998), Gabriele D'Annunzio. Defiant archangel, Oxford : Oxford University Press 


\section{Paratextual material}

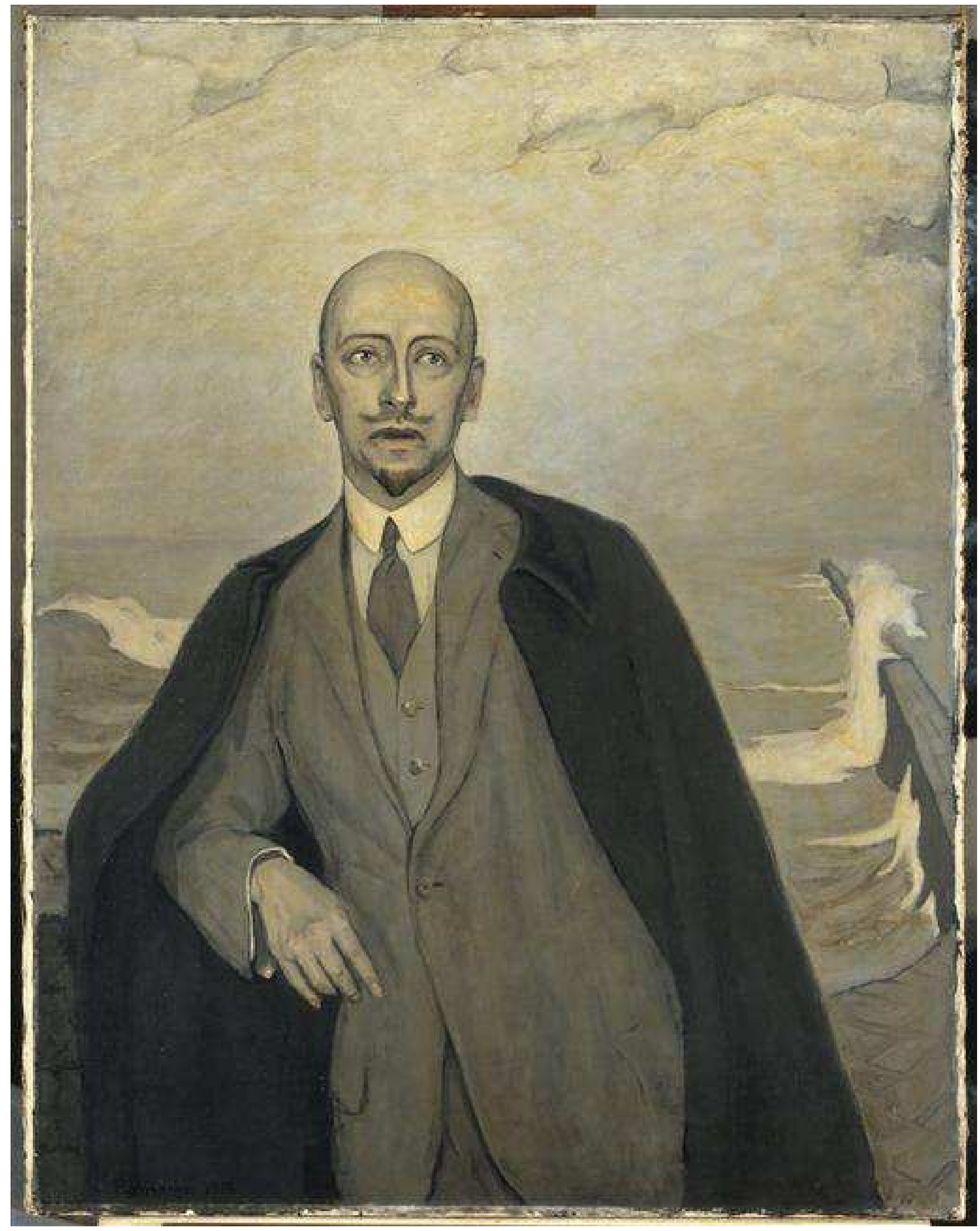

Portrait by Romain Brooks, 1912, oil on canvas, Collection Centre Pompidou http://www.photo.rmn.fr/cf/htm/CPicZ.aspx?E=2C6NU0VN1J7E 


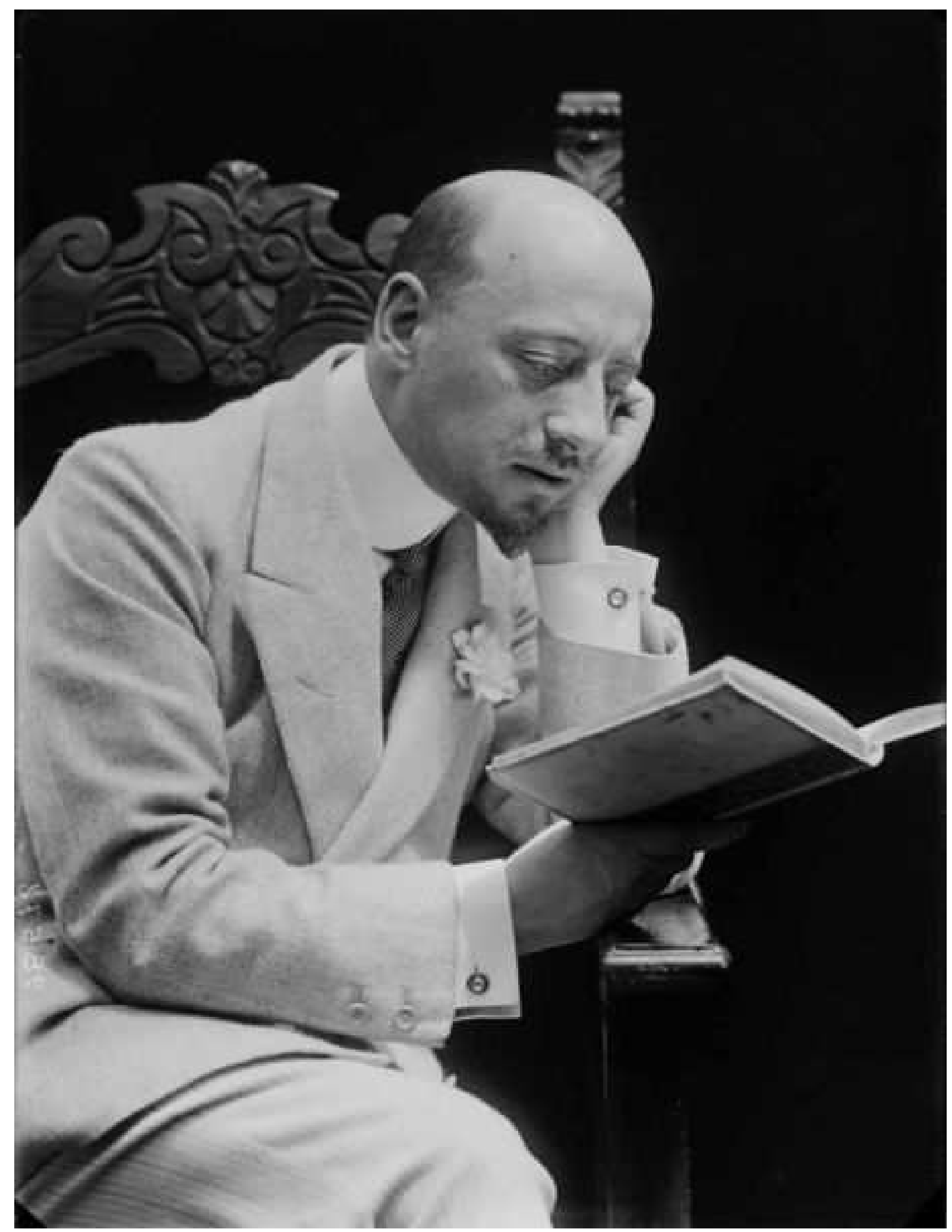

Gabriele d'Annunzio portraied by Mario Nunes in 1906, Museum Casa Natale di Gabriele d'Annunzio

http://www.casadannunzio.beniculturali.it/index.php?it/23/le-opere/36/stanza-vi-foto-1-ritratto-digabriele-dannunzio-realizzato-da-mario-nunes-nel1906 


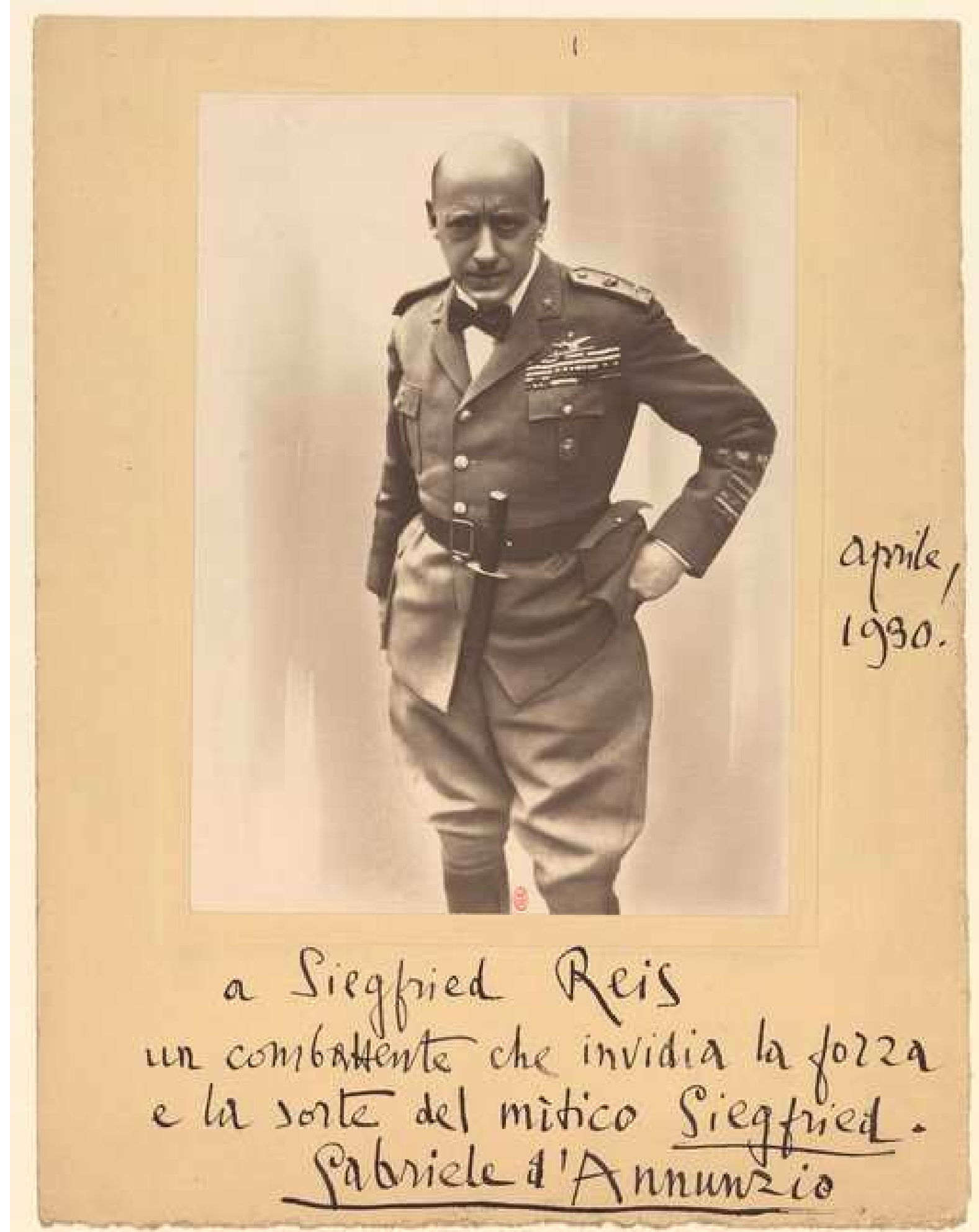

\section{日 $0757 \times 0$}

Text: "To Siegfried Reis, a fighter who envies the power and the fate of the legendary Siegfried. Gabriele d'Annunzio, April 1930.

http://visualiseur.bnf.fr/CadresFenetre?O=IFN-8538778\&I=5\&M=chemindefer

For the same picture with no text see http://it.wikipedia.org/wiki/Gabriele_D\%27Annunzio 


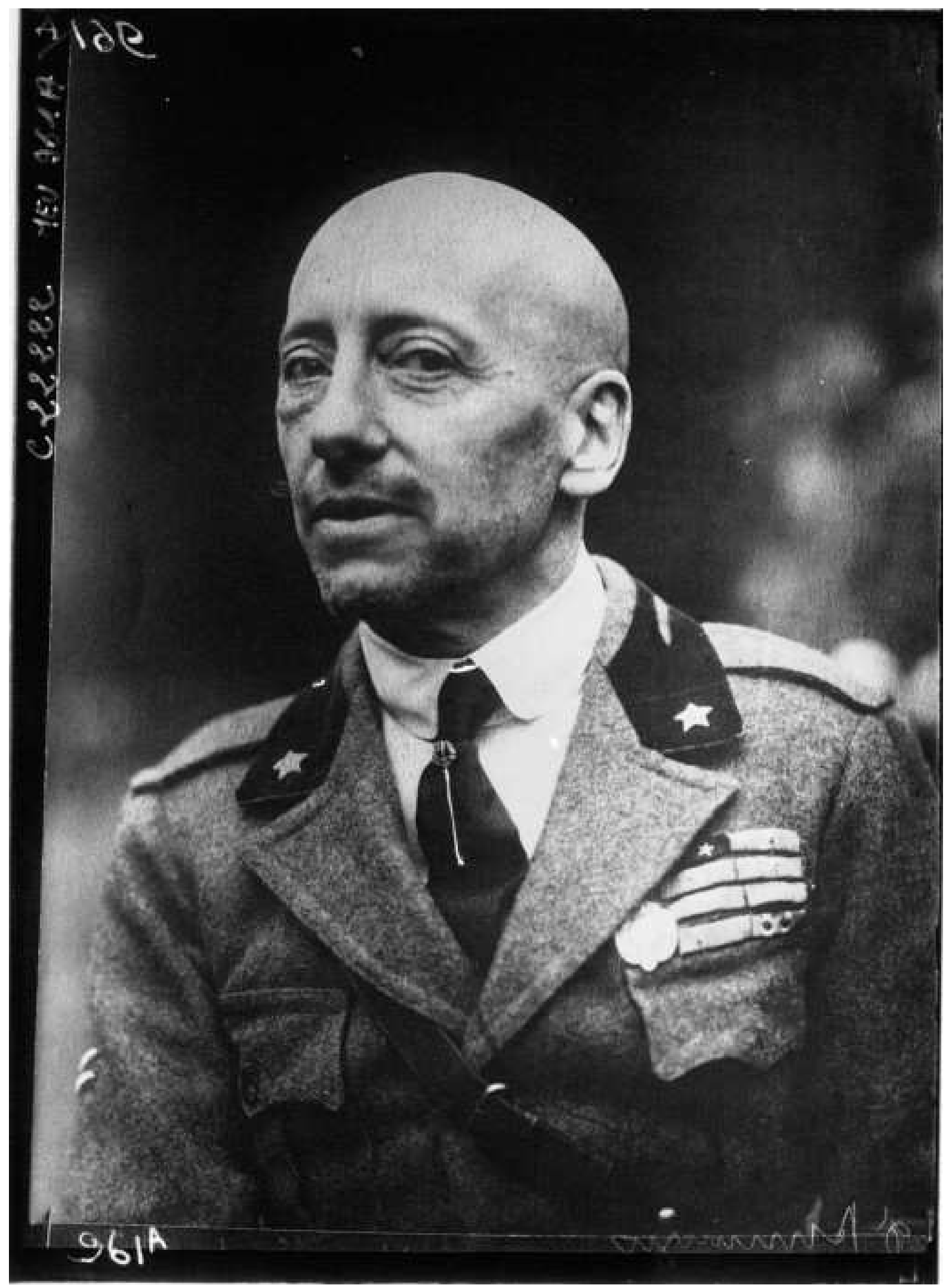

http://visualiseur.bnf.fr/CadresFenetre?O=IFN-9054684\&I=1\&M=chemindefer 